\title{
ENTREVISTA
}

\section{ALUÍZIO ALVES:}

\section{Estamos Brasil a limpo}

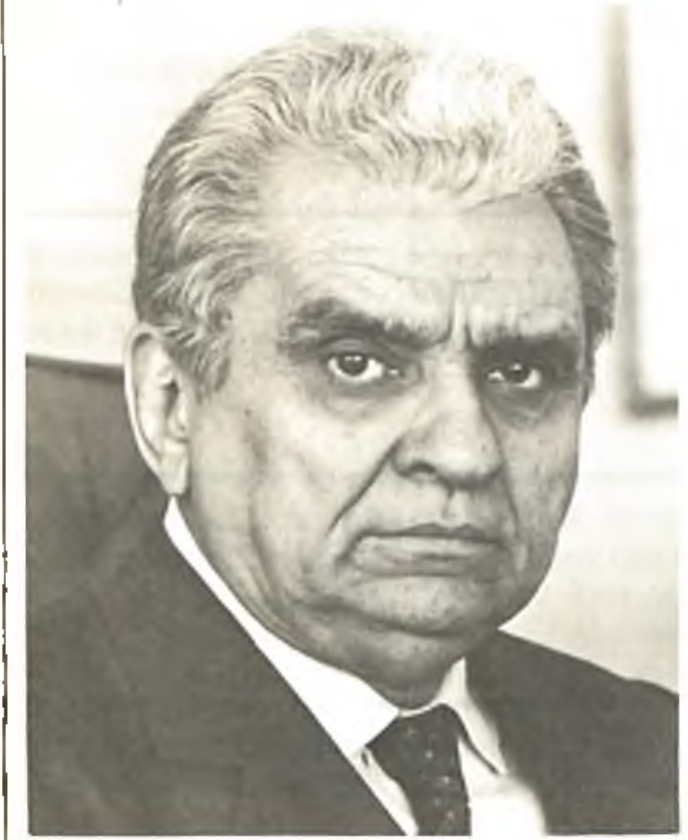

'Nós estamos passando o Brasil a limpo. O Brasil de vinte anos de regime autoritário, de concentraçāo de poder, de corrupçāo, de erros acumulados. Tudo isso näo se corrige em dez meses, nem durante o mandato do Presidente Sarney. Esse é o trabatho de uma geraçâo".

"Nós queremos prepararo poder para ser exercido em nome do pova fiscalizado pelo pova através dos órgāos de representaçāo, através da imprensa, através da crítica de cada brasileiro, e queremos dar, a esta administraçäo, agilidade e eficiência".

As frases são do Ministro Aluizio Alves no programa Brasil-Entrevista, produzido pela EBN para 314 emissoras de rádio de 1odo o País. Participaram como entrevistadores os jornalistas Hélio Fernandes, da Tribuna do Imprensa (RJ); Covas Júnior, do Rádio Record (SP); Anselmo Gama, da Rádio Cultura do Pará; e Adriano de Souza, da Tribuna do Norte (Natal). Segue-se a integra da entrevista:

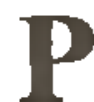
ergunta - Como é que o senhor rebateria as duras crilicas feitas pelo ex-Ministro RoberIn Gusmão? Estes nove, quase dez meses de Ministério, valeram todos os sacrifícios, compensaram, ou quem esıá com a razão é o ex-Ministro Gusmāo?

Aluizio - Vamos colocar a questāo dentro de um plano geral. Em primeiro lugar, Gusmāo e eu somos amigos de trinta anos. Pensamos em muitas coisas de modos diferentes, mas, fundamentalmente, pensamos certo, quando desejamos um regime democrático, consolidado, no Brasil, e uma administração pública à altura das necessidades do País. Agora, acontece o seguinte: Gusmảo vem da iniciativa privada para a vida pública e está acostumado, na iniciativa privada, às coisas serem decididas com toda a rapidez. Na administraçāo pública, essa rapidez é inviável, mesmo que se tratasse de uma boa organização. $\mathbf{F}$ não se trata. Tanto ele, como eu, e antes de nós dois o Presidente da República, José Sarney, já dissemos que a administração pública, no Brasil, é emperrada, é incompetente, é desorganizada, é lerda. Agora, discordamos, aqui, de novo, eu e o Gusmão. Ele acha que se pode fazer uma reforma administrativa magicamente. Baixa-se um decreto, faz-se uma lei e reforma-se a administração pública. Eu acho que nós não vamos fazer da reforma administrativa uma coleção de leis. Nós vamos criar um esıado de espírito na sociedade, para que ela exija uma administração pública ágil, 


\section{ENTREVISTA}

racional, competente. Nós vamos criar uma nova mentalidade do funcionalismo, estimulando-o a fazer, do seu trabalho, uma tarefa nobre, uma tarefa da qual se orgulhe. Nós vamos procurar uma administraçāo racional para um pais que é um continente, onde os problemas e as soluçōes de Brasília necessariamente não servem para as soluçōes dos problemas de Natal, nern de Belém, nem do Amapá. Então nós temos problemas, ora de concentração de poder, ora de descentralização do poder. Ora de concentração de comando, de orientação, de supervisāo, e problemas de descentralizaçāo da execução, de descentralização relativa da fiscalização, etc. Isso, o Gusmão deve ter sentido, na hora em que pensou que poderia extinguir, rapidamente, o IAA, o IBC, a Embratur, órgāos cuja organização nāo tinha a sua simpatia.

E o que ele fez? Ele fez uma auditoria externa, que nāo podia ter grande valor legal, teve que partir para uma comissão de sindicância, chegou a conclusões diferentes da autarquia, ai "embananou", e ele não pôde tomar providências, pois a auditoria exrerna era uma firma privada que não entendia de administração. A comissāo de sindicância, teoricamente, devia conhecer mais, ter uma opiniāo diferente sobre os fatos, objetos de sindicância e objetos da auditoria. Então, ele encomendou à Fundap Fundação da Administração Pública, do Estado de São Paulo, uma nova estrutura para esses órgāos e está saindo do Ministério - porque vai se desincompatibilizar no prazo legal, para ser candidato - sem, sequer, receber esse estudo, sem, portanto, re solver esse problema. Isto em relação a três pequenos órgãos: o IBC, o IAA e a Embratur.

Você avalia, apenas, o que é uma reforma administrativa de toda administração pública, desde a administração civil à administração militar, desde a Presidência da República à Funai; de 425 empresas públicas, desde a Petrobrás, no seu gigantismo, até uma pequena empresa em qualquer um destes Estados, com problema de salários, de quadro de pessoal, de admissāo, de objetivos, as superposiçōes e os conflitos? Você tem o Ministério da Reforma Agrária exatamente com as mesmas finalidades do Incra. O In-

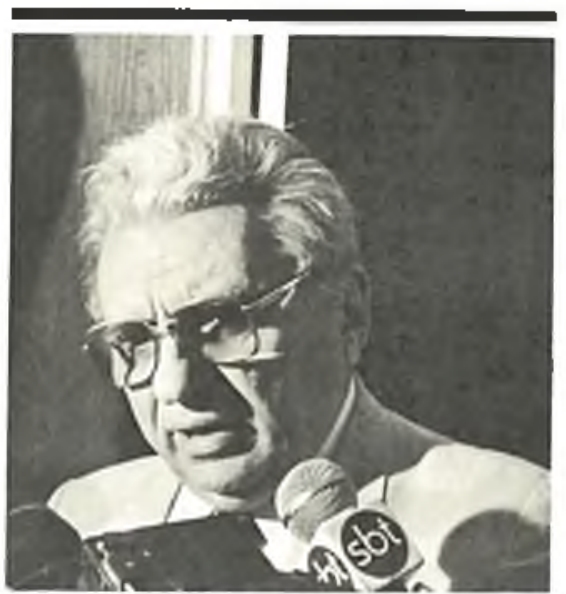

tas em regime autoritário, no Estado Novo e na Revolução.

Baixa-se um decreto, hoje, sai no Diário Oricial, amanhā, e se transforma em lei. Agora não, nós temos que repensar toda a administração pública brasileira, nós temos que examinar as estruturas, as formas de execução, as formas de fiscalizaçāo, a programação orçamentária, o controle das despesas, o relacionamento entre Poder Legislativo, Poder Executivo, Poder Judiciário, Tribunais de Contas, etc. Só de empresas, são 425, e, algumas, gigantescas, como é a Petrobrás, como é a Vale do Rio Doce. Só de repartiçōes, são vinte e tantas mil repartições. Cada uma com problemas diferentes. Algumas com funcionários estatutários, funcionários celetistas, de tabelas especiais, de tabelas emergenciais, funcionários trabalhando mediante pagamento por recibo, outros que nāo sāo funcionários, mas, são prestadores de serviços, fornecidos por empresas privadas, contratadas. Identificar todos esses problemas, organizar todas as soluçōes, leva tempo. Mas, mesmo que se tivesse de fazer isto, ainda há dois problemas: nāo adianta você chegar e dizer "eu vou fazer isto, a partir de amanhā, a repartição vai se organizar assim", se você não criar uma mentalidade para isto. Se você, realmente, não criar um estado de espirito novo, no funcionalismo, e começar por um gigantesco e massivo trabalho de treinamento do funcionalismo. Nós somos dois milhōes de funcionários no País. O órgão, que foi criado, em 8I, para treinar funcionários, o órgão do Governo Federal, a Funcep, de 81 a 85, treinou cinco mil, em dois milhões. Você vê, por ai, como estamos longe de chegar àquele momento em que os funcionários estarão preparados para executar, competentemente, as suas tarefas. Portanto, para concluir, o que há é o seguinte: as críticas de Gusmão, ao emperramento da máquina, à incompetência da máquina, à lentidão da máquina, eu subscrevo e até acrescento algumas, que talvez ele não conheça, porque ele estava restrito à atuação do MIC. Agora, a maneira de executar, de fazer a reforma, de implantar essa re forma é que não pode ser como ele quer. Ele viu que não pode ser, na hora em que teve o seu próprio problema. E nós 


\section{ENTREVISTA}

vamos levar algum tempo. Isto é um processo que está se inciando, com a participação de 36 especialistas, representantes das associaçōes de funcionários, nâo é urna reforma que se f́aça por decreto, por mágica. E uma reforma que é uma mudança de mentalidade e do pensamento da administraçāo pública brasileira.

Pergunta - Quando se realizará a reforma administrativa ampla, que o senhor anunciou no inicio do Governo da Nova República. Quando teremos essa medida, Ministro? O Governo vai ter coragem, mesmo, de fato, de começar a reformular a máquina adminisirativa, $\mathrm{cm}$ um ano eleitoral, quando a pressāo dos polílicos é muilo grande?

Aluizio - "Antes de responder a essas perguntas, eu quero dizer uma palavra a Hélio Fernandes, que me fez uma pergunta de maneira geral, se esses nove meses de Ministério valeram a pena, Iodo o sacrifício que foi realizado. Eu acho que valeram. Nós estamos realizando uma tarefa imporrante. Nós estamos passando a limpo o Brasil. O Brasil de vinte anos de regime autoritário, de concentraçāo de poder, de corrupçāo, de erros acumulados. Tudo isso nâo se corrige em dez meses, nem durante o mandato do Presidente Sarney. Esse é o trabalho de uma geraçāo. E nos cabe, apenas, durante o Governo Sarney, fazer o esforço que pudermos fazer. Esse esforço, nós estamos fazendo, porque, ao mesmo rempo, estamos implantando um Ministério novo, um Ministério que nāo existia. Estamos dando as linhas, os delineamentos de sua estrutura. Isso leva tempo, exigem sacrificio, exige trabalho, mas, realmente, vale a pena fazer o esforço. Quanto à pergunta de Paulo Mesquita, da Rádio Pampa de Porto Alegre, eu acho que ele tem razāo de cobrar a reforma administrariva anunciada. Apcnas, clc há de compreender, que se querem apenas um decreto-lei, ou mesmo só um projeto, é fácil. Isso, em 24 horas, nós preparamos. Agora, nós nāo queremos isso, nós queremos uma nova filosofia da administraçāo, em que o poder não seja apenas o dominio de uma casta à margem do povo.

- Nós queremos preparar o poder, para ser exercido em nome do povo, fiscalizado pelo povo, através dos

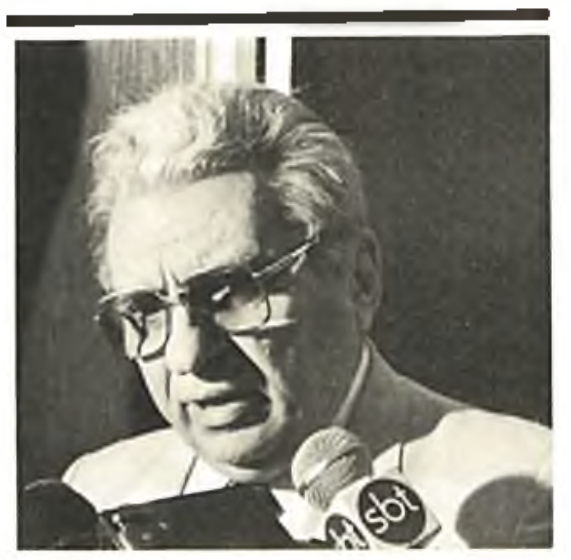

$M$

uitas repartições vão desaparecer, muitas serâo fundidas, oulras mudaräo de Ministério, com melhor adaptaçäo. E um trabalho que será feito. $O$ povo $e$ os funcionários têm de ter paciência, que isso tudo vai mudar. Organizar vinte e tantas $\mathrm{mil}$ repartiçōes, 425 empresas, a vida de dois milhöes de funcionários, não é trabalho para um ano.

órgãos de representaçâo, alravés da imprensa, através da crítica de cada brasileiro, e queremos dar, a essa administração, agilidade e eficiência. Agora mesmo, estamos implantando o Serviço Nacional do Protocolo Ele trônico. Quando eu cheguei no Ministério, eu encontrei processos que vinham se arrastando há sete anos. Um processo de um funcionário, vamos dizer, do Estado do Pará, ou do Amapá, dá entrada e começa aquele delírio: vai pra uma mesa, vai pra outra, parecer nāo sei de quê, carimbo nāo sei de quê, volta, e se a pessoa não está acompanhando todo o dia, aqucle processo nâo anda. Porque, como o número de funcionários, muitas vezes, para tratar deles, é menor, é bem pequeno, em relaçāo ao número de processos, vinte mil, trinia mil, 60 mil, $200 \mathrm{mil}$ processos, que andam, ai, pelas repartiçōes, então, aqueles que nāo estāo sendo objeto de pressão do interessado, vão ficando encostados. Você entāo vai fazer o quê? Ou vai todo dia à repartição, ou toda a semana, gasta dinheiro cm iransporte, gasta gasolina do seu carro, ou entāo tem que constituir um procurador, e esse procurador passa a ser uma nova despesa sua, para obter o resultado. Nós estamos fazendo o Protocalo Eletrônico, pelo qual, em qualquer parte do Pais, você saberá, em cada capital, aonde poderá entregar o seu processo. Aquele processo vem para o $\mathrm{Mi}$ nistério da Administração, recebe um número nacional. Depois de receber um número, passa por um grupo de análise, para ver onde ele deve ir e qual será mais ou menos o prazo que ele deve passar, em cada uma dessas repartiçōes. Fixa-se o prazo c, aí, o processo entra no malote, que será entregue, através do Serviço de Mala Oficial, que também estamos criando.

- Entāo, aqucle processo é acompanhado pelo computador passo a passo, dia-a-dia. De qualquer parte do Brasil, se alguém quiser notícia desse processo, tem essa notícia dentro de um minuto, basta que ligue: 06I-1515, que é o número do Protocolo Eletrônico. Imediatamente, ele é atendido, e diz o número do processo, ou até o nome do interessado, se quiser. Ele pode ser atendido pelas duas coisas, pelos dois sistemas. Imediatamente, ele irá dizer: o processo entrou no dia tal, foi para tal repartiação, está com tal f́uncionário, o telefone desse funcionário é número tal, que the dará a informaçāo precisa. $\mathrm{E}_{1}$ de mês em mês, o Ministério da Administraçâo recebe do computador uma relaçāo dos processos que estāo fora dos prazos que foram estabelecidos, ou para corrigir esses prazos, se os prazos foram mal fixados, ou para reclamar, se, apesar do prazo, o processo estiver demorando. Quer dizer, isto vai dar, realmente, uma nova velocidade à administraçāo pública, no que toca aos papéis. Agora, nós vamos fazer da reforma um processo. Estamos, agora, incluindo a discussão do Estatuto do Funcionário Público. Você há de dizer: "Born, mas fazer o Estatuto, quando vem uma nova Constituiçảo?" Pensamos nisso, mas a Constituição scrá elaborada em 87, você, entāo, só poderia fazer esse Estatulo em 88, daqui até lá, vocể ia continuar com o Estatuto que foi 


\section{ENTREVISTA}

feito em 52, já foi reformulado mil vezes, por decisões judiciais, por conquistas obtidas junto ao próprio $\mathrm{Po}$ der Executivo, etc. Então nós resolvemos fazer o processo e, se a Constituiçāo modificar alguns pontos, que estão fixados no processo, é muito mais fácil mudar apenas aqueles pontos c atualizar o processo. Depois vamos votar a I ei Orgânica da Administração Federal. Esta, sim, será a Lei Matriz. A organização federal vai se organizar através de um sistema cen[ral, de um sisterna vinculado e de um sistema empresarial. Entāo nós vamos dividir em organizações indiretas, vinculadas ao Serviço Público, em empresas pủblicas, fundaçōes, sociedades de economia mista, que vāo constituir um ramo da administração pública, e os Ministérios e as repartiçôes a eles subordinadas.

- Agora, em relaçāo a funcionários. Nós, hoje, temos funcionários dos vários regimes. Celetistas, pagos por recibo, sem registro nenhum, estatutários. Talvez vocês não saibam que o último funcionário estatutário admitido no Brasil foi em 61. De lá pra cá, foi tudo regime celetista. Resultado: há, hoje, 125 mil funcionários estatutários, para um milhão e oitocentos mil funcionários celetistas. Então não há um quadro de funciorário público, porque a Consolidação das Leis do Trabalho permite que você, pagando o Fundo de Garantia demila codos os funcionários. Não há um quadro estável. E é isto que nós vamos fazer. Nós vamos fazer o seguinte: quem trabalha na administraçāo direta, só pode ser estatutário. Quem trabalha na administração indireta, só pode ser celetista. Vamos estabelecer os dois regimes juridicos de trabalho, e vamos dar um prazo de opção. Funcionário analisa as vantagens: estatutário, eu tenho a aposentadoria integral, eu tenho qüinqüênios, eu tenho estabilidade, com dois anos, para citar algumas das vantagens. Ah, mas eu prefiro ser celetista, porque eu tenho estabilidade, tenho aposentadoria parcial, mas, em compensaçāo tenho o Fundo de Garantia, tenho um quadro maior, mais fácil, porlanto, de alcançar promoçôes. Entảo, ele, dentro de seis meses, dirá: eu quero ser estatutário, entāo vai para a administração direta; eu quero ser celetista, então vai para a

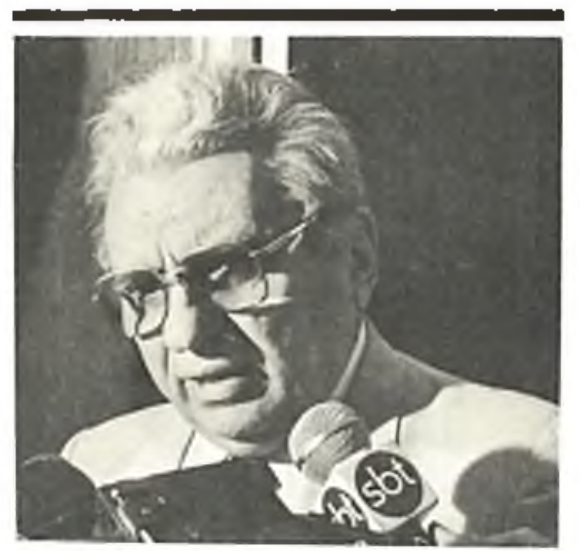

cargos em comissão serão apenas ministro de Estado, secretário geral, assessores, chefes de gabineres e secretários gerais de serviços. Dai pra baixo, de diretor a contínuo, de diretor a servente, é uma carreira, que se entra por concurso e vai. Você entra como agente administrativo e vai fazendo cursos internos e concursos internos e vai crescendo à medida de sua competência, até chegar a diretor da sua repartição, à medida, ou de outra repartição. Entāo, você tem uma carreira estável, e o Pais passa a ter uma estrutura mais estável, que independa de uma mudança de Governo, a continuidade da máquina, como existe em todos os paises. Agora, quando será isto? Está começando. Vem o Estaluto, vem depois a Lei Orgânica da Administraçâao Federal, virá depois lei de licitaçōes, depois, virá o programa de treinamento. Em vez de fazermos um projeto só, uma lei só, para implantar de repente, magicamentc, nós vamos fazer um processo e vamos implantando, pouco a pouco, vamos arrumando a máquina e, par aisso, já tomamos, este ano várias providências. $\mathrm{Na}$ hora em que nós enquadramos os $136 \mathrm{mil}$ funcionários das tabelas especiais, nāo consideramos apenas os seus problemas pessoais, as suas educações. Consideramos a necessidade de organizar a política de pessoal. Na hora em que nós estamos já em dois reajustes, o dc julho e o de janeiro, concedendo reajustes iguais para civis, militares, funcionários do Poder Legislativo, funcionários do Poder Judiciário, nós estamos, apenas, limpando o terreno, organizando, evitando que se acumulem essas distorções que haviam, funcionários com a mesma função ganhando de maneira diferente. Então, esse trabalho está sendo feito, estamos corrigindo muitas distorçôes e para quê?

- Para que, sobre esse trabalho, se faça um Plano de Classificação de Cargos, uma carreira de funcionários, um plano de retribuiçōes. Porque hoje você nāo roma pé. Por lei você tem quat ro gratificaçōes. $\mathrm{Na}$ realidade você tem $\mathbf{4 4}$ tipos de gratificaçōes.

- Aparecia uma greve, aparecia um grupo de prestigio no poder hoje conseguia uma gratificação para aquele grupo. Entāo, você tem hoje em vez de vencimentos, que por lej 
são 60 , você tem 344 . Nós estamos limpando o terreno, organizando essas coisas, para que a Lei Orgânica da Administraçāo Federal encontre os caminhos de fixar as diretrizes da administração. E, aí, vão desaparecer muitas repartiçōes, vāo sc fundir muitas outras, vão mudar de um Ministério para outro, com melhor adaptaçāo, e estc é um trabalho que nós vamos fazer. $\mathrm{O}$ povo tem que ter paciência, os funcionários têm que ter paciência, que isso ludo vai mudar, a organização de vinte e tantas mil repartiçōes, a vida de dois milhōes de funcionários, empresas públicas que sāo $\mathbf{4 2 5}$ empresas - estabelecer uma estrutura racional, ágil, nāo é trabalho nem para um ano, nem para o Governo Sarney sozinho. Nós vamos fazer, vamos iniciar, vamos deflagrar e vamos deixar que os outros Governos conrinuem esse trabalho.

Pergunla - $O$ ano eleitoral não vai alrapalhar a deflagração do processo?

Aluizio - Acé agora, estou convencido que nāo e mantenho esta convicçào pela seguinte razāo: o Governo Sarney assumiu no dia quinze de março e no día 17 proibiu todas as nomeaçôes da administ raçāo direta, quando se sabia que quem estava chegando ao poder - PMDB etc - estava há vinte anos no ostracismo, devia quercr nomear funcionários e foi proibida a admissāo. E, aí, começaram a admitir na administraçāo indirela. No dia 8 de junho, vcio um decrero estendendo à administ raçâo irdireta, também, essa proibiçāo. Quando foi agora, no dia 8 de dezembro, dia de terminar o prazo da proibição até 31 de dezcmbro, foi prorrogada até 30 de junho. Porlanlo, não houve pressāo de natureza política e nem pressāo de natureza eleitoral que impedisse o Governo de tomar essas rigorosas medidas de contençāo de economia e de racionalizaçāo da máquina pública.

Pergunta - Pnr que um cidadão hrasileiro com mais de $\mathbf{3 0}$ anos nào pode participar de concurso público no Brasil? Tamhém gostaria de saber se este limite de idade é também para funcinnários que já exercem funções púhlicas no País.

Aluizio - O problema de idade, no scrviço público, tem uma limitaçào que nós ainda nāo temos manei-

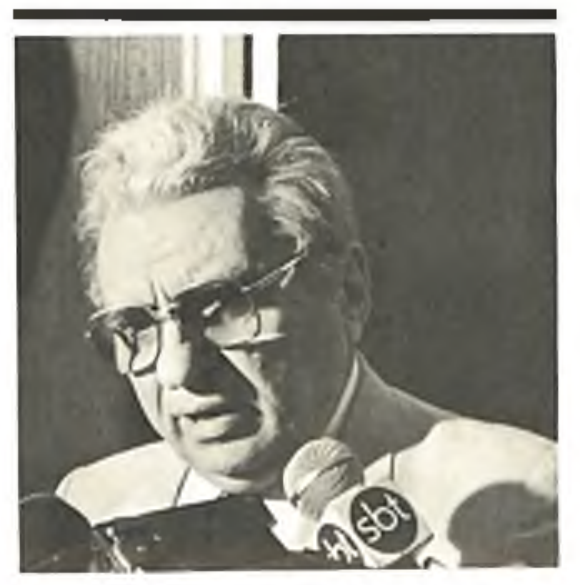

Pergunta - 0 que o Ministério da Adminisıração tem feilo para acabar com a discriminação en|re os funcionários públicos e os trabalhadores, no que se refere a indice salarial, direilo à sindicalização e direito de greve? Quando será possível conceder décimo-1erceiro salário a todos os servidores da Uniāo?

Aluizio - O problema é o seguinte: você não pode querer uma rigorosa igualdade de situaçôes, entre o funcionário público e os trabalhadores da iniciativa privada. Até pelo seguinte: o funcionário público tem esrabilidade com dois anos, tem aposentadoria integral, nāo paga contribuição para ter csses benefícios. $O$ trabalhador paga essas contribuiçôes para ter beneficios, nāo tem estabilidade, mas tem Fundo de Garantia, nāo tem qüinquiênio. O funcionário público trabalha para a Uniāo ou para o Estado ou para os Municipios. O5 trabalhadores trabalham para empresas, ora grandes, ora pequenas ricos ou pobres, situaçōes salariais diferentes. Agora, lanto quanto possivel, nós temos procurado corrigir a enorme defasagem que houve nos últimos anos entre os salários dos empregados da iniciativa privada e os do funcionário público. E o exemplo é este: nos últimos anos, sobretudo em 79 a 84 , os salários da iniciativa privada foram sempre crescendo mais do que o dos funcionários públicos, mas no ano de 85 , considerando esta situação, o Governo, apesar de todas as dificuldades financeiras, deu uma reposição salarial bem maior do que tiveram os funcionários da iniciativa privada.

- Os empregados da iniciativa privada que tiveram reposiçāo maior foram os que tiveram $12 \%$. O Banco do Brasil, que é do Governo, mas organizado por uma iniciativa privada, e as empresas em geral, deram reposição de 4,5 aré $8 \%$. O funcionário público teve uma reposiçāo de $25 \%$, porque a in17ação foi de $233 \%$. E a soma dos dois reajustes, o de julho e o de janeiro, foi de $\mathbf{2 5 8 \%}$. Teve uma reposiçāo de $25 \%$, a mais alta reposiçāo já conseguida, inclusive comparando-sc com o Banco do Brasil, mesmo empresas grande c lucra(ivas. lsto, num ano de déficit público, num ano de dificuldades financeiras. 


\section{ENTREVISTA}

- Quando à sindicalização e djreito de greve, a sindicalização nāo é proibida pela Constituição. Ela é proibida pela Consolidaçāo das Leis do Trabalho. Dependeria de uma reformulação da CLT, que é tarefa do Ministério do Trabalho. Mas seria, de certa maneira, inútil, fazer está reformulaçâo, agora, e eu já converseí sobre isto com o Ministro Pazzianolto, porque o direito de greve está proibjdo para o funcionário na Constituiçāo, então nāo adianta organizar sindicatos, se ele nāo tem a sua principal arma, o direito de greve. Então resolvemos esperar pela Nova Constituiçāo. Se a Constituição, amanhã, disser que o funcionário público tem direito à sindicalização $\mathrm{e}$ ao direito de greve, é fácil regulamentar, mas pode ser que a Canstituinte pense de maneira diferente. Por quê? Porque, no caso, há uma diferença filosófica muito importante. O empregado de uma firma, quando faz greve, está prcjudicando, teoricamente, o patrão, que não está lhe dando as condições de trabalho, que ele deseja. Quando - funcionário público faz greve, ele nāo está prejudicando o Estado, ele está prejudicando a sociedade. Entāo é preciso que, no estabelecimento do direito de greve e sindicalizaçāo, sc examinem essas diferenças 7 losóficas, da tarefa do funcionário público e da tarefa do trabalhador privado. O que não quer dizer que eu não concorde com a sindicalização e com o direito de greve. Confesso, entretanto, que ainda não tenho uma opiniāo muito firme a respeito. Quarito ao décimoterceiro salário, há o seguinte: o décimo-terceiro salário é uma reivindicação de $125 \mathrm{mil}$ funcionários, apeлas, porque os outros, todos do regime celetista, já têm. Um milhāo e oitocentos já recebem, só os estatutários nāo têm, o que é uma injustiça. Eu lutei muito para conceder, em 85 , e só nāo consegui porque nós tínhamos uma limitação financeira para o reajuste do funcionalismo público $e$ chegou uma hora em que, ou nós conseguiamos o décimo-terceiro salário ou conseguiamos um aumento maior. O décimo-terceiro salário ia beneficiar, apenas, $125 \mathrm{mil}$, a diferença maior do reajuste ia beneficiar todo - funcionalismo público, e nós achamos que era preferivel optar por esta decisão. Então, pesando todas essas

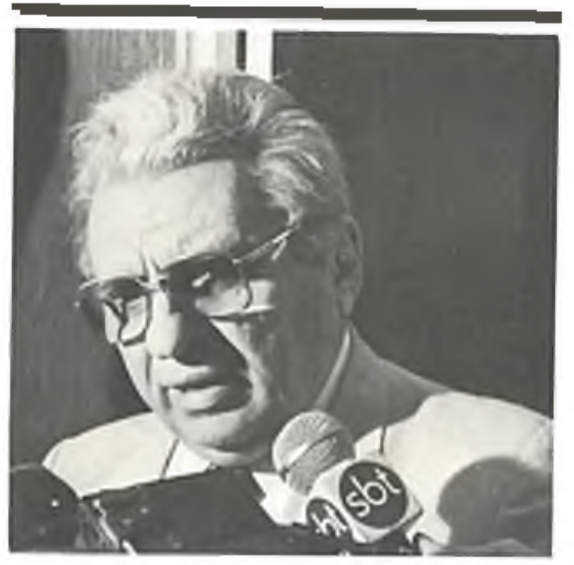

\section{H \\ stá sendo implantado o \\ Serviço Nacional de \\ Protocolo Eletrônico que, \\ em cada capital, permitirá \\ ao interessado saber para \\ onde mandar seu processo \\ e depois ter informaçōes \\ precisas do seu andamento, \\ bastando telefonar para \\ Brasilia. O processo terá \\ prazo fixado para solução $e$ \\ será acompanhado passo \\ a passo, dia-a-dia, pelo \\ serviço de computador.}

razões, se eu pudesse, eu teria dado também o décimo-terceiro salário, mas como o recurso não era suficiente para as duas coisas, eu preferi dar um reajuste maior para todos, do que o décimo-terceiro salário apenas para $125 \mathrm{mil}$, que já tinham benefícios de quatro ou de dois ou três qüinqüênios acumulados.

Pergunta - Como será a novo Estgtu1o do Funcionalismo Público Civil da Uniāo, e os regimes Esıatutário e Celetis1a conlinuarão?

Aluízio - A nossa idéia é fazer o seguinte: funcionários da administraçāo direta e autarquias, só estatutários. Funcionários da administraçâo indireta, cconomia mista - fundaçōes e empresas públicas a inПexibilidade do regime do funcionário público, em que você nāo pode demitir depois de dois anos. Mas, por outro lado, você nāo pode dar à adminis- tração pública direta, a instabilidade do regime da CLT, porque, de uma hora para outra, chegaria uma administração nova, paga o Fundo de Ga rantia c demite rodos os funcionários. E a repartição? Como iria reconstituir o seu quadro de pessoal? Entāo, nós vamos dividir, assim. O Esıaluto regulará apenas a siluaçāo dos funcionários estatutários. Minha idéia era outra, era fazer funcionário estatutário e funcionário celetista. Mas, mesmo ministro, presidente da comissão, perdi no plenário esta questāo. O plenário preferiu fazer o Estatuto do Funcionário Público só para o estalurário, e fazer depois o Estatuto para o empregado celetista. Então, nós estamos tratando, na reunião do dia 17, 18, de concluir o novo Estatuto do Funcionário Público, fixando bem essas condições.

Pergunta - Ministro, foi feito, pelo Governo Federal, a leilâo e venda de carros oficiais, de chapa hranca, que eram utilizados, indevidamente. Com a venda desses veículos, qual o procedimento para a fiscalizaçāo dos carros chapa hranca, que ainda estāo em circulaçẽo?

Aluizio - Vamos distinguir bem essas situações, porque há uma certa confusāo quanto a carros oficiajs: o carro de representação, que, em geral, é zquele de chapa de bronze: o carro de serviço, que é o carro chapa branca: e há o carro utilitário, que é o caminhão, o jipc, para serviços que não transportem passageiros, e, além do mais havia, e ainda deve haver, o chapa fria, que a gente ainda não conseguiu eliminar de todo, e eu vou expljcar por que.

- Entāo, o que fizemos? Primeiro, havia dois mil e trezentos carros dc representação, nós reduzimos a (rezentos e noventa. Por quê? Quem tinha chapa de bronze: ministro, secretário geral, os secretários, chefes de gabinete, os assessores, etc. Então nós achamos, esta decisāo não foi minha, foi de uma comissão de mordomias presidida pelo Ministro do Planejamento - que só o Ministro de Estado, o secretário, e presidentes de aurarquias, tinham direito a carro de chapa de bronze. Então, caímos para 390 carros. Isto representa uma eco nomia, por ano, de 95 bilhōes de cruzeiros. Agora, além desses carros, tem os carros de serviço, que no País são 


\section{ENTREVISTA}

27 mil e aqui em Brasília sāo dois mil e setecentos.

- Estamos organizando a Central de Carros Oficiajs. O Presidente deve assinar o decreto logo. Por esta Central, o Ministério da Administraçāo se encarrega de todo o transporte de serviço das repartiçōes públicas e dos serviços de correspondência, através dos serviços de mala oficial, que também será objeto de um outro decreto, a ser baixado, dentro de poucos dias. Entāo, você terá, na garagem do Ministério da Administraçāo, um determinado número de carros, que, equipados com serviço de rádio, atenderāo os chamados dos Ministérios. Com isto, em vez de dois mil e setecentos carros, ficará com 400 carros, e elimina uma grande parte das despesas, os abusos.

- Agora, nāo esperem milagre. Nós vamos começar servindo só os Ministérios do lado direito da Esplanada. Vamos corrigir os erros e as deficiências, treinar o pessoal, e depois incorporaremos a Presidência da República, se houver interesse, o Poder Legislativo, e assim por diante, então vamos ter realmente uma melhor qualidade de serviço, uma economia muito grande de combustivel e pessoal, uma rapidez muito melher e um controle muito maior, uma moralização muito maior no uso dos carros ofjciais.

- Vamos dar, portanto, uma grande economia à Naçāo; vamos dar uma melhor qualidade de serviço e moralizar o uso do carro oficial.

Pergunta - A genle sabe que a preocupação do Governo com a moralidade no Serviço Público lem sido uma constante No enianio, no Nordeste, a gente não vê medidas efetivas para acabar com esse lipo de coisas. Alagoas, por exemplo, um Estado pequeno, ande a maioria dos servidores públicos ganha salário mínimo, lem na Assembléia Legislativa do Fsiado, uma leva de servidores ganhando salários superiores a $175 \mathrm{mi}$ Ihões de cruzeiros. Agora, mesmo o Diário Ofícial do Estado publicou uma relaçāo de 353 marajás, com saJários variando de 10 a 45 milhões. Nós gostariamos de saber qual é a posiçāo do ministro, que medidas efetivas ele pode 10mar para acabar de vez com esta imoralidade que ataca os nossos Estados?

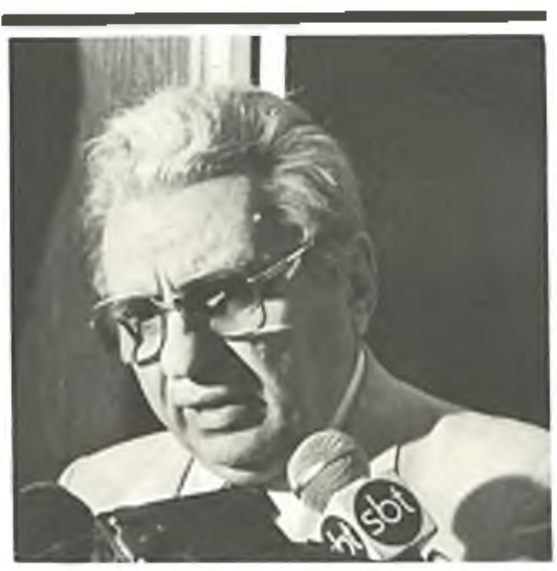

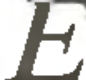 \\ stá sendo organizada a Central de Carros Oficiais} $e$, com ela, o Ministério da Administraçào ficará encarregado de todo $o$ transporte de serviço das repartições públicas, da correspondência e malas oficiais. A previsão é de que isto significará uma redução da frota de 2.700 para apenas 400 veículos. O servico comecará pelo lado direito do Esplanada.

Aluízio - Eu fiquei espantado quando tomei conhecimento dessa situação, e, em certo momento, no ano passado, o Governador do Estado pediu a nossa intervençāo. Nós dissemos que o Ministério nāo poderia fazer nada, porque o Estado é autônomo, o Ministério tem a ver com o funcionalismo federal. Quem regula a vida, os salários, a sicuação dos funcionários estaduais é o Estado. Quem regula a vida dos funcionários municipais é o Município. Mas, através de uma intermediaçāo amigável, nós mandamos um alto funcionário do Ministério. Lá estava aquele problema: o Governador nāo queria pagar o aumento da Assembléia, a Assem bléia tinha feito o aumento legalmente, mas, a meu ver, imoralmente. Então, chegou-se a um acordo, e houve uma reduçāo substancial. Havia uma pressāo da opiniāo pública. E a Assembléia terminou aceitando uma re- dução, mesmo assim, ficando com salários muico mais altos do que o funcionalismo federal. Mas, já agora, no final do ano, alguns deputados, provavelmente com medo de nāo se reelegerem e que sofrerem pressão dos funcionários, voltaram a aumentar abusivamente os vencimentos dos funcionários. E aí nāo há o que fazer, porque nem o Governador pode vetar, porque a Assembléia é autônoma. Ela é quem decide sobre os seus vencimentos. Entāo, a única forma que eu vejo de uma solução, é de, na futura Constituiçāo, nós encontrarmos uma maneira de dizer o seguinte: "O funcionário estadual, do Poder Executivo, Legislativo ou Judiciário nāo pode ganhar mais do que o funcionário federal, ou terá de ganhar até $10 \%$ menos do que ganha o funcionário federal".

Pergunta - É verdade que o senhor convocou todo o seu Ministério para ficar de plantão duranle o carnaval?

Aluízio - Você quer me incompalibilizar com os funcionários? Se eu fizesse isso, seria deposto pelos funcionários. $\mathrm{O}$ que aconteceu foi o seguinte: em todas as repartiçōes há os que gostam do carnaval e há os que não gostam de carnaval. Eu, por excmplo, nāo gosto, mas eu admito que você goste. Entāo eu fiz uma pesquisa. Quem não vai brincar carnaval? Sem dizer para que era. E quem vai ficar em Brasilia? Entāo eu peguei aqueles que responderam que nāo jam brincar carnaval e que nāo jam sair de Brasília e convidei-os para trabalhar comigo durante o carnaval. Aos que vāo brincar carnaval desejo muita alegria, aos que vāo viajar, desejo bom passeio; agora, aos que vão ficar aqui, vāo ficar em casa, olhando um para o outro, nāo, vão para o trabalho, porque prestam um serviço à naçāo, desempenham mais a sua capacidade de trabalho e então nós vamos dar expediente, realmente, no Ministério, no sábado, no domingo, na segunda, na terça e na quartafeira, como se fosse um dia normal de trabalho. Mas ninguém é obrigado, só aqueles que não gostam de carnaval e só aqueles que nāo vão sair. É uma forma de protestar contra o carnaval, ou uma forma de nāo ter inveja dos que estão brincando o carnaval. 